\title{
Pelaksanaan Model Discovery Learning Jerome Bruner pada Pembelajaran PAI di SMPN 3 Depok Sleman Yogyakarta
}

\author{
Winarti \\ Universitas Islam Negeri Sunan Kalijaga Yogyakarta \\ winarti101096@gmail.com \\ Suyadi \\ Universitas Islam Negeri Sunan Kalijaga Yogyakarta \\ suyadi@uin-suka.ac.id
}

Naskah diterima: 7 Agustus 2020 | Disetujui: 10 Oktober 2020 | Diterbitkan: 20 Oktober 2020

\begin{abstract}
There is a common problem in the learning process of Islamic Religious Education (PAI), which still uses merely light methods or strategies; such as the simple lecture method uncombined with other participatory methods as discussion, memorization, and questioning. Therefore, it takes a gait to implement learning strategies that can make students more active in understanding new concepts and experiences by applying Jerome Bruner's Discovery Learning method. This qualitative research conducted by classroom observation and interviews by implementing the model in PAI learning at SMPN 3 Depok Sleman Yogyakarta. The research shows that the model had been carried out well through the following procedures: providing stimulation, identifying problems, gathering information and data, processing data, then proving and drawing conclusions; as well as supported by several supporting factors (the integrated curriculum, teachers' pedagogical mastery, and adequate infrastructures). Despite there are several obstacles, the learning strategy is promising.
\end{abstract}

Keywords: Cognitive, Discovery Learning Model, implementation, Islamic Religious Education.

\begin{abstract}
Abstrak
Terdapat masalah umum dalam proses pembelajaran Pendidikan Agama Islam (PAI) yang masih menggunakan metode atau strategi pembelajaran sederhana, seperti metode ceramah tanpa dipadukan dengan metode partisipatif lain seperti diskusi, hafalan, dan tanya jawab. Oleh karena itu, dibutuhkan upaya untuk menerapkan strategi pembelajaran yang dapat membuat siswa lebih aktif dalam memahami konsep dan pengalaman baru, salah satunya dengan menerapkan metode pembelajaran Discovery Learning dari Jerome Bruner. Penelitian kualitatif ini dilakukan dengan observasi kelas dan wawancara dengan mengimplementasikan model Discovery Learning dalam pembelajaran PAI di SMPN 3 Depok Sleman Yogyakarta. Hasil penelitian menunjukkan bahwa model pembelajaran tersebut telah dilaksanakan dengan baik melalui prosedur sebagai berikut: memberikan stimulasi, mengidentifikasi masalah, mengumpulkan informasi dan data, mengolah data, kemudian membuktikan dan menarik kesimpulan; serta didukung oleh beberapa faktor pendukung (kurikulum yang terintegrasi, penguasaan pedagogik guru, dan sarana prasarana yang memadai). Meski ada beberapa kendala, namun strategi pembelajaran ini cukup menjanjikan.
\end{abstract}

Kata Kunci: Kognitif, Model Discovery Learning, Implementasi, Pendidikan Agama Islam. 


\section{Pendahuluan}

Pendidikan ialah aktivitas dengan makna maupun tujuan tertentu yang diarahkan guna mengembangkan potensi yang telah dimiliki manusia ataupun masyarakat dengan seutuhnya (Nurkholis, 2013). Pendidikan juga diartikan sederhana sebagai usaha yang dilakukan manusia guna membina kepribadian yang sesuai dengan nilai-nilai di masyarakat, budaya, maupun agama. Namun pada praktiknya, menjalankan pendidikan secara maksimal tidaklah semudah membalikkan telapak tangan. Banyak sekali persoalan atau masalah yang harus dihadapi dalam menjalankan pendidikan di berbagai tempat. Salah satu dari persoalan tersebut yang paling mendasar adalah mengenai strategi atau model pembelajaran yang diterapkan oleh guru (Windi, Akbar, \& Sugandi, 2019).

Pengamatan penulis di lapangan, salah satunya di SMPN 3 Depok Sleman Yogyakarta pada tanggal 21 April 2020, menunjukkan adanya siswa yang tidak terlibat aktif dalam pembelajaran, mengalami suasana belajar yang pasif, dan mengakibatkan terhambatnya kemampuan berfikir siswa tersebut terhadap informasi yang ada. Hal tersebut disebabkan karena penggunaan strategi atau model pembelajaran yang diterapkan tidak tepat, sehingga tidak mendorong aktifnya suasana belajar siswa. Menurut Murdiwiyono (2020), selaku Kepala Sekolah, agar siswa termotivasi dan aktif dalam pembelajaran, guru dianjurkan memakai model pembelajaran yang mampu mengaktifkan siswa secara menyeluruh agar dapat membangun pembelajaran yang aktif. Salah satunya adalah dengan cara penemuan pengalaman yang baru, yakni dengan penerapan model pembelajaran Discovery Learning (belajar penemuan).

Pembelajaran hakikatnya ialah proses aktif, di mana terdapat interaksi antar siswa dengan sumber belajar maupun pendidiknya. Dengan kata lain, ada proses komunikasi yang terarah guna menuju target atau tujuan yang telah ditentukan (Dasopang, 2017). Pembelajaran dikatakan sukses jika siswa secara merata semangat, percaya diri, serta aktif fisik dan mentalnya. Seseorang dikatakan belajar jika ada perubahan pada dirinya, seperti dari tidak mampu membaca menjadi mampu membaca (Dahar, 2006). Dalam aktivitas belajar mengajar peserta didik sebagai subjek maupun objek dalam pendidikan, kegiatan pembelajaran dikatakan tercapai jika peserta didik berusaha terlibat aktif dalam kegiatan pembelajaran. Tujuan pembelajaran akan tercapai jika fisik maupun mentalnya sama-sama aktif, karena hakikat belajar ialah perubahan pada diri individu setelah melaksanakan aktivitas belajar.

Di antara teori belajar yang digunakan dalam pembelajaran adalah teori belajar kognitif. Menurut Kosmiyah (2012), teori belajar kognitif adalah pengorganisasian aspek kognitif dan persepsi untuk memperoleh suatu pemahaman. Salah satu tokoh psikologi kognitif, Jerome Bruner, mendefinisikan belajar ialah suatu proses aktif dalam hal menghasilkan sesuatu yang baru yang didapat dari informasi yang telah diberikan kepada individu (Sutarto, 2016). Dalam teori kognitif, pengetahuan dibuat untuk diri seseorang secara sendiri dalam proses pertemuan antara individu satu maupun lainnya. Kognitif mengedepankan proses dibandingkan hasilnya (Perdana, 2019). Menurut pengikut kelompok Bruner, belajar tidak sekedar mengaitkan rangsangan maupun tanggapan, karena belajar ialah suatu proses berfikir yang dalam (Uno, 2006).

Teori Kognitif dari Jerome Bruner sangat penting untuk dipelajari dan dipahami karena membangun individu dalam mengembangkan pengetahuan (Ningsih, 2012). Teori ini menekankan segala sesuatu yang didapat harus ditangkap maupun dipahami agar mendapatkan pengalaman yang baru. Agar pengetahuan lebih bermakna, maka siswa diberi peluang oleh guru dengan leluasa untuk 
menemukan konsep secara mandiri. Menurut Bruner, belajar yang baik ialah memahami konsep, maksud, serta hubungan melalui proses intuitif selanjutnya, sehingga dihasilkan suatu kesimpulan. Model pembelajaran seperti ini sama dengan belajar dengan cara menemukan (discovery learning) di mana siswa berperan aktif dalam pembelajaran hingga mampu menganalisis materi dan berfikir mendalam (Bambang, 2018).

Sebagai salah satu mata pelajaran yang wajib, Pendidikan Agama Islam memiliki tujuan untuk menanamkan maupun meningkatkan religiusitas seseorang lewat pengetahuannya, serta penghayatannya atas apa yang telah didapat sebagai hamba Allah yang taat atau beriman (Majid, 2014). Dengan demikian, dapat dimengerti juga bahwa Pendidikan Agama Islam ialah usaha dalam membina, mendorong seseorang agar lebih baik, membentuk pribadi yang sempurna, yang berhubungan dengan hati nurani, akal perbuatan maupun perasaan seseorang.

Sebagai mata pelajaran yang wajib diajarkan, maka pendidikan agama Islam perlu diajarkan dengan sebaik mungkin seperti mata pelajaran yang lainnya. Banyak dijumpainya metode maupun strategi kuno yang ada pada pembelajaran PAI, seperti metode ceramah yang tidak dikombinasikan dengan metode-metode yang lain seperti diskusi, hafalan, ataupun tanya jawab dengan cara yang sangat pasif mengakibatkan proses pembelajaran menjadi monoton. Hal tersebut menjadikan siswa sulit mencapai pengetahuan yang didapatnya dengan cara memahami konsep dan sampai kepada kesimpulan (Widyawati, 2014).

Salah satu sekolah yang menerapkan model pembelajaran Discovery Learning adalah SMPN 3 Depok Sleman Yogyakarta. Sekolah ini adalah sekolah yang menerapkan perpaduan kurikulum 2013 dan kurikulum Pendidikan Holistik Integratif (PHI) dan banyak menorehkan prestasi tingkat nasioanal maupun internasional dalam bidang akademik maupun non-akademik. Tentunya sistem pembelajaran juga didesain dengan kreatif dan inovatif dalam memenuhi tuntutan zaman. Dalam wawancara dengan guru PAI di sekolah tersebut, Nurjannah (2020), didapati bahwa SMPN 3 Depok menerapkan pelaksanaan pembelajaran Discovery Learning dengan harapan siswa bisa aktif maupun fokus dalam memahami konsep dan kesimpulan atau penemuan pengalaman yang baru.

Berdasarkan latar belakang tersebut, tujuan dari penulisan artikel ini adalah untuk mengetahui proses pelaksanaan model Discovery Learning pada mata pelajaran Pendidikan Agama Islam di SMPN 3 Depok, serta mengetahui apa yang menjadi faktor penghambat dan pendukung dalam menerapkan model tersebut.

\section{Metode}

Penelitian ini merupakan penelitian kualitatif lapangan (field research) dengan pendekatan psikologi dan menggunakan teori kognitif pandangan Jerome Bruner. Teknik pengumpulan data yang peneliti gunakan ialah observasi ke SMPN 3 Depok Sleman Yogyakarta dengan mengamati aktivitas pembelajaran di kelas VII, wawancara dengan Kepala Sekolah, Guru PAI yang mengajar dan siswa-siswi di kelas tersebut, serta studi dokumentasi terkait dengan penelitian. Dari observasi yang dilakukan, maka subjek penelitian ialah siswa-siswi kelas VII, Guru PAI yang mengajar di kelas tersebut, dan Kepala Sekolah. Analisis data dilaksanakan dengan tiga tahapan dan melalui tiga jalur analisis data kualitatif yaitu reduksi data, penyajian data dan penarikan kesimpulan. Reduksi data adalah upaya menyimpulkan data, kemudian memilah-milah dalam satuan konsep tertentu, kategori tertentu, dan tema tertentu. Penyajian data adalah kegiatan ketika sekumpulan informasi 
disusun sehingga memberi kemungkinan akan adanya penarikan kesimpulan serta pengambilan tindakan (Rinjani, 2018).

\section{Model Pembelajaran Discovery Learning (Belajar Penemuan) Jerome Bruner}

Menurut Jerome Bruner, pengetahuan perlu dipelajari secara dalam dan memiliki tahap-tahap tertentu agar pengetahuan tersebut bisa terinternalisasi dalam fikiran (struktur kognitif) tiap individu yang telah mempelajarinya. Proses internalisasi akan berjalan sungguh-sungguh jika proses pembelajaran terjadi secara maksimal. Dalam proses pembelajaran, individu harus aktif dan kreatif dalam menemukan suatu cara pemecahan masalah berdasarkan pengalaman-pengalaman dan penemuan yang diperoleh dari proses pembelajaran (Widyaningrum, 2015). Model pembelajaran ialah pola interaksi oleh guru dan siswa yang berkaitan dengan strategi, metode, pendekatan, maupun teknik yang dilaksanakan dalam kegiatan belajar mengajar di kelas. Jerome Bruner ialah salah satu tokoh yang pertama kali mengemukakan model pembelajaran Discovery Learning untuk mendorong siswa aktif di dalam kelas dengan mengajukan pertanyaan-pertanyaan menarik.

Model Discovery Learning, menurut Bruner, ialah suatu cara dalam menyampaikan gagasan melalui proses penemuan yang dilakukan oleh siswa. Siswa akan memperoleh penemuan melalui proses mengamati, mengukur, memahami, menjelaskan dan dapat menyimpulkan materi pengetahuan yang diperoleh dalam pembelajaran. Dalam model ini, pembelajaran diatur sedemikian rupa sehingga siswa menjadi terlatih aktif dan memperoleh pengetahuan yang mereka belum ketahui. Dengan kata lain, guru hanya sebagai pembimbing dan memberikan arahan kepada siswa, sedangkan siswa dibiarkan secara mandiri dalam menemukan pengetahuan (Sibuea et al., 2019). Namun, dalam proses pembelajaran ini, guru tetap berperan penting, karena harus mampu mendorong dan menciptakan kondisi pembelajaran yang aktif dan pemahaman siswa menjadi lebih bermakna (Amallia, Redhana, 2017). Dengan melatih siswa aktif menemukan sendiri, memecahkan masalah sendiri, menganalisis, dan melakukan suatu pengalaman yang didapat sesuai perkembangan zaman, maka nanti hasilnya akan bertahan lama dalam ingatannya (Hosman, 2014).

Manfaat pembelajaran Discovery Learning ialah bisa meningkatkan kemampuan berfikir siswa, melatih memori ingatan dengan cara aktif pada siswa, sehingga menemukan suatu pengalaman yang baru (Dwi \& Rahayu, 2017). Dengan mengaplikasikan model ini, pendidik hendaknya membawa murid dalam mengatasi problem-problemnya secara mandiri ketimbang mengarahkannya melalui tanggapan-tanggapan yang diberikan oleh pendidik.

Dengan model pembelajaran Discovery Learning, terjadi pelibatan secara maksimal seluruh kemampuan siswa sehingga mereka mampu berfikir kritis, logis, dan sistematis sehingga mampu merumuskan sendiri penemuannya. Karena pengetahuan yang diperoleh siswa akan bertahan lebih lama dan mudah diingat, maka Discovery Learning dapat menghasilkan transfer ilmu dengan baik sehingga mampu meningkatkan keterampilan dan cara berfikir yang kritis (Jones \& Hilaire, 2012).

Selain memiliki keunggulan dalam peningkatan pemahaman pada siswa secara keseluruhan, seperti aspek pengetahuan, sikap maupun keterampilan pada siswa tersebut, namun jika Discovery Learning diterapkan pada kelas yang terlalu besar akan menjadikan pembelajaran tidak efektif karena guru sulit mengontrol kegiatan pembelajaran di kelas. Dalam pembelajaran Discovery Learning, siswa yang mempunyai pemahaman yang lambat dalam memahami materi akan tertinggal, sedangkan siswa yang mempunyai pemahaman yang tinggi akan lebih cepat menguasai 
konsep dalam pembelajaran. Dengan dituntutnya siswa dalam memperoleh konsep dan penemuan pengetahuan yang baru secara mandiri dan aktif, maka diperlukan waktu yang cukup banyak. Karena jika tidak diberikan waktu yang banyak, maka hasil dari pembelajaran tersebut tidak sesuai dengan tujuan dan target yang hendak dicapai. Kelemahan dari pembelajaran tersebut bisa diatasi dengan memadukan dengan unsur dalam pembelajaran lain yang sesuai, antara lain dengan dipadukan model accelerated learning (Priyayi, Sajidan, \& Prayitno, 2015).

Terlepas dari kelemahannya jika diterapkan dalam kelas besar, secara umum kelebihan dari model pembelajaran Discovery Learning ialah (Mutmainna, 2015):

1) siswa akan terbantu dalam menguasai dan memahami keterampilan dalam pembelajaran karena menjadikan siswa aktif dan mendorong rasa ingin tahu

2) pengetahuan yang didapat secara mandiri oleh siswa akan menjadikan pemahaman pada siswa secara mendalam dan meresap sehingga bertahan lama

3) siswa akan lebih bersemangat dan bergairah dalam mengikuti pembelajaran di kelas

4) kemampuan siswa akan lebih berkembang karena siswa diberikan kesempatan secara penuh

5) siswa akan lebih percaya diri karena diberikan kepercayaan dengan cara memahami, mengolah, dan mencari konsep pengetahuan yang baru.

Secara praktis, beberapa langkah atau prosedur yang harus dilaksanakan dalam Discovery Learning adalah sebagai berikut (Purwaningrum, 2016):

a. Stimulation (pemberian rangsangan). Dalam fase ini, siswa dihadapkan atas suatu problem yang memicu kegelisahan dan didorong untuk mendalami secara mandiri. Guru mengawali tindakan yang bertujuan untuk pemecahan problem, memberikan pertanyaan maupun anjuran membaca buku tertentu.

b. Problem Statement (pernyataan maupun identifikasi kasus). Dalam fase ini siswa menjelaskan, menganalisa, menggali problem maupun persoalan yang dihadapi. Hal tersebut dilakukan untuk mengondisikan siswa agar terbiasa atau terlatih untuk mendapatkan kasus, persoalan, maupun problem.

c. Data Collection (pengumpulan informasi maupun data). Guru membuka keleluasaan siswa guna mengumpulkan penjelasan informasi sebesar-besarnya.

d. Data Prosessing (pengolahan atau pengerjaan data). Mengolah Informasi (data) yakni tindakan (aktivitas) yang pernah ditangkap siswa lewat tanya jawab atau pengamatan.

e. Verification (pembuktian), di mana siswa melaksanakan pengontrolan dengan jeli dan teliti guna meyakinkan akurasi anggapan atau asumsi yang ditemukan, akhirnya digabungkan buah informasi (bukti).

f.Generalization yakni kegiatan akhir siswa dalam menarik pendapat kesimpulan, teknik atau cara untuk menyelesaikan problem. 


\section{Pelaksanaan Model Discovery Learning (Belajar Penemuan) pada Pembelajaran PAI di SMPN 3 Depok Sleman Yogyakarta}

Pelaksanaan Model Discovery Learning di SMPN 3 Depok Sleman Yogyakarta diawali peneliti dengan pengamatan di kelas VII pada tanggal 21 April 2020. Dalam pengamatan pada mata pelajaran PAI tersebut, didapati bahwa guru memulai pembelajaran dengan mengucap salam, memandu berdoa, memeriksa kehadiran dan memberikan motivasi kepada siswa. Kemudian guru mengulang materi pembelajaran pada minggu sebelumnya agar siswa mengingat kembali materi yang telah diberikan.

Langkah pertama dalam pelaksanaan model Discovey Learning yaitu Stimulation (pemberian rangsangan). Dalam fase ini, siswa dihadapkan pada problem yang memicu kegelisahan dan didorong untuk mendalami secara mandiri. Guru memberikan rangsangan berupa permasalahan. Hal tersebut dilakukan guna memancing siswa mendalami materi secara individu dan agar siswa berusaha memecahkan permasalahan yang telah diberikan. Perangsangan dalam hal ini, bertujuan mempersiapkan suasana hubungan belajar yang aktif dan mampu membangun siswa mendalami materi. Permasalahan yang diberikan berupa Bab Fiqih Muamalah pada materi Sewa-Menyewa (Ijarah).

Langkah kedua yaitu Problem Statement (pernyataan maupun identifikasi kasus). Guru memberikan kesempatan kepada siswa mengidentifikasi masalah. Siswa mengidentifikasi masalah studi kasus sebagai berikut:

Roni mempunyai ruko. Sebagai pemilik ruko, Roni mempersilahkan kepada Bayu selaku tetangganya untuk memanfaatkan ruko tersebut tanpa memberikan beban biaya sewa. Tetapi di suatu ketika, Roni sedang terlilit hutang. Kemudian Roni pun meminta kepada Bayu agar membayar sewa ruko tersebut sebesar 25\% dari pendapatan atau keuntungan bisnis Bayu.

Guru kemudian meminta siswa agar memberikan tanggapan, bagaimana seharusnya Roni menyelesaikan permasalahan terlilit hutang tanpa memberikan beban biaya sewa kepada Bayu.

Setelah dibuat rangsangan dan identifikasi kasus, kemudian guru mengizinkan siswa untuk menjelaskan bagaimana cara pemecahan masalah sesuai kasus yang telah diberikan di atas. Siswa harus bersungguh-sungguh aktif dalam mendapatkan suatu objek dan bahan yang berkaitan dengan problem yang dihadapkan. Siswa harus mampu mengaitkan problem dengan pemahaman dan pengetahuan yang telah diperoleh. Guru memberikan tanya jawab dan keseluruhannya dijawab oleh siswa dengan baik. Pada tahap selanjutnya, siswa menarik kesimpulan dari permasalahan tersebut sehingga bisa mendapatkan penemuan pengalaman atau pengetahuan yang baru.

Langkah ketiga, Data Collection (Pengumpulan Informasi maupun Data). Siswa mengumpulkan informasi melalui pencarian materi dari jurnal, buku-buku, dan mengamati objek. Siswa melakukan uji coba secara mandiri yang berhubungan dengan Bab Fiqih Muamalah. Hal tersebut dilakukan untuk pembuktian terhadap benar atau tidaknya hipotesis. Dari cara siswa mengidentifikasi masalah studi kasus Bab Fiqih Muamalah dapat dilihat dari informasi yang ada di contoh studi kasus mengenai riba yang dilakukan oleh Roni, kegiatan tersebut merupakan contoh riba yang tidak diperbolehkan dalam Islam karena dalam kasus ini Roni mengingkari janji, yang pada awalnya tidak membayar sewa tetapi di tengah periode meminta sewa tersebut dengan alasan atau penyebab apapun. 
Langkah keempat, Data Processing (Pengolahan atau Pengerjaan Data). Siswa mengerjakan atau mengolah data dan menganalisis materi yang telah ditentukan. Siswa mengolah data yang ada di dalam studi kasus mengenai riba yang dilakukan oleh Roni dengan meminta sewa kepada Bayu sebesar 25\% dari keuntungan Bayu. Hal tersebut memberikan dampak yang tidak baik pada perekonomian Bayu, karena pada perjanjian awalnya tidak bernegosiasi mengenai biaya sewa tersebut. Namun dalam kenyataannya di tengah periode Roni dengan tiba-tiba meminta keuntungan dari sewa tersebut.

Langkah kelima, Verification (Pembuktian). Siswa memeriksa data yang telah diperoleh dengan teliti dalam membuktikan benar atau tidak hasil dari hipotesis terkait studi kasus yang dikaji. Dari kasus tersebut, siswa membuktikan bahwa kegiatan riba adalah kegiatan yang tidak baik, tidak diperbolehkan dalam Islam. Karena dengan melihat kejadian tersebut menggambarkan bahwa riba sangat membahayakan bagi orang yang sedang membutuhkan dana untuk suatu kebutuhan. Di sisi lain, siswa juga dapat membuktikan bahwa pentingnya rukun sewa menyewa (ijarah) untuk dipenuhi sejak awal, sehingga tidak mengakibatkan permasalahan di kemudian hari.

Langkah keenam, Generalization. Siswa menarik kesimpulan dari permasalahan tersebut, sehingga bisa mendapatkan penemuan pengalaman dan pengetahuan yang baru. Dari kasus di atas siswa menyimpulkan bahwa kegiatan yang dilakukan Roni awalnya sangat membantu Bayu dalam perekonomiannya dalam memanfaatkaan ruko tersebut. Tetapi karena di tengah periode, tiba-tiba Roni mengambil keuntungan dari sewa ruko yang awalnya tidak ada perjanjian sehingga menimbulkan riba pada kegiatan tersebut, maka perilaku Roni kepada Bayu pada kasus tersebut tidak baik.

\section{Hambatan dan Pendukung dalam Penerapan Model Pembelajaran Discovery Learning}

Sebagaimana lazim dalam tiap model pembelajaran, dalam model Discovery Learning pun juga terdapat penghambat atau kendala yang dihadapi siswa. Dalam menganalisis dan menjelaskan pengetahuan, banyak siswa yang aktif. Tetapi ada sebagian dari siswa cenderung pasif dikarenakan setiap anak mempunyai kemampuan yang berbeda-beda. Hal tersebut pasti ada faktor pendukung maupun faktor penghambat. Di antara faktor pendukung tersebut adalah, dalam pembelajaran guru menguasai cara-cara membuat kelas menjadi hidup (menyenangkan) dan guru menggunakan bahasa yang luwes, sehingga mudah dipahami oleh siswa. Menjadikan siswa aktif dalam kegiatan belajar, sebab mereka berfikir dan menggunakan kemampuan untuk menemukan hasil akhir. Siswa memahami benar bahan pelajaran, karena mengalami sendiri proses menemukan. Sesuatu yang diperoleh dengan cara ini lebih lama diingat. Proses menemukan yang dilakukan secara individu menimbulkan rasa puas pada diri siswa. Kepuasan batin ini mendorong keinginan melakukan penemuan lagi, sehingga minat belajarnya meningkat. Siswa yang memperoleh pengetahuan dengan menemukan akan lebih mampu mentransfer pengetahuannya ke dalam berbagai konteks.

Berdasarkan wawancara dengan Miftakul Jannah (2020), guru PAI di kelas VII SMPN 3 Depok Sleman, ditemukan bahwa hambatan dari adanya penerapan model Discovery Learning, yaitu; membutuhkan waktu yang cukup banyak. Jika tidak terpimpin dan terarah dengan baik, maka akan membawa ke dalam kekacauan terhadap materi yang akan dipelajari dan menuntut siswa untuk memiliki persiapan maupun kematangan mental dalam dirinya. Siswa harus mampu berani menangkap dan memahami suasana yang ada di sekitar mereka dengan baik dan terarah. 
Sementara itu, menurut pengakuan Rosiyah dan Sholahudin, siswa kelas VII SMPN 3 Depok Sleman yang menjadi subyek penelitian, mereka merasa bahwa pelaksanaan model Discovery Learning mempermudah mereka dalam membangun atau mengembangkan potensi yang dimiliki. Dengan model ini, mereka menjadi terlatih dalam mengembangkan keterampilan yang telah dimiliki di dalam proses kognitif. Selain itu, siswa mendapatkan pengetahuan yang bersifat individu yang dapat bertahan lama dalam dirinya. Mereka pun merasa senang dan bersemangat dalam belajar, karena memiliki pengalaman berusaha mencari pengetahuan dari dalam dirinya sendiri. Oleh karenanya, hal tersebut akan membentuk belajar yang timbul pada rasa keikhlasan dan aktif. Ringkasnya, dengan model Discovery Learning, siswa berkesempatan untuk mengembangkan bakat yang ada dan memberikan rasa percaya diri.

Menurut Murdiwiyono (2020), Kepala SMPN 3 Depok Sleman, dalam pelaksanaan model pembelajaran biasanya ditemukan faktor yang menjadikan penghambat dan pendukung. Dalam pembelajaran yang telah dilaksanakan di SMPN 3 Depok, faktor pendukung dalam model Discovery Learning di antaranya sebagai berikut;

1) Kurikulum yang telah diterapkan di sekolah ialah Kurikulum 2013 yang memadukan Pendidikan Holistik Integratif (PHI). Dalam kurikulum ini, salah satu metode pembelajarannya adalah dengan memberikan pengalaman secara langsung kepada siswa. Siswa mendalami, menganalisis, mengembangkan maupun menyimpulkan, sehingga siswa bisa menemukan pengalaman yang baru dalam pembelajaran.

2) Guru mempunyai penguasaan pedagogik yang baik, sehingga mampu menyampaikan materi pembelajaran Discovery Learning secara baik dan maksimal.

3) Sarana maupun prasarana yang memadai dan mendukung guru dalam menerapkan Discovery Learning kepada peserta didik dengan baik.

Tidak dapat dipungkiri bahwa sebuah pembelajaran akan berjalan dengan baik dan maksimal jika melibatkan guru maupun peserta didiknya secara optimal. Jika dilihat hambatan dalam model Discovery Learning, yang timbul dari peserta didik yakni semangat dan kemampuan yang berbedabeda antara peserta didik yang satu dengan yang lainnya menjadikan peserta didik sulit aktif dalam pembelajaran. Tidak semua peserta didik mempunyai kemampuan menganalisis dengan baik sehingga sulit dalam menarik kesimpulan dan menemukan pengalaman yang baru dari pembelajaran tersebut.

\section{Kesimpulan}

Berkaitan dengan penelitian di atas, di SMPN 3 Depok Sleman Yogyakarta sudah menerapkan Teori Kognitif Jerome Bruner yang dikenal dengan Discovery Learning (belajar penemuan) dengan baik. Dampak dari penerapan model tersebut, diketemukan bahwa terdapat faktor pendukung seperti kapasitas dan kompetensi guru, antusiasme dan kemampuan dasar siswa, hingga kurikulum dan sarana pra sarana yang memadai. Di sisi lain didapati juga bahwa terdapat beberapa faktor penghambat, yakni keterbatasan model ini jika diterapkan pada kelas besar atau pada kelas yang rentang kemampuan dasar siswanya cukup lebar. Dengan adanya kedua faktor pendukung maupun penghambat tersebut, maka diperlukan kejelian dari pihak guru maupun 
pemangku kebijakan kurikulum di sekolah untuk memutuskan apakah model Discovery Learning ini dapat diterapkan atau tidak, dengan mempertimbangkan kondisi kelas yang akan diajar.

\section{Bibliografi}

Amallia, N \& Redhana, I. W. (2017). Penerapan Model Pembelajaran Discovery Learning Untuk Meningkatkan Kemampuan Berpikir Kritis dan Hasil Belajar Kimia. Jurnal Pendidikan Kimia Indonesia. UNDIKSHA, Jurnal Pendidikan Kimia Indonesia, Vol. 1(No. 1), 23.

Bambang, W. (2018). Teknologi Pembelajaran: Landasan dan Aplikasinya,. Jakarta: Rineka Cipta.

Buto, Z. A. (2018). Implikasi Pembelajaran Jerome Bruner dalam Nuansa Moderen. Almillah, Vol. 02 (No. 01), 30.

Dahar, R. W. (2006). Teori-teori Belajar dan Pembelajaran. Bandung: Erlangga.

Dasopang, A. P. (2017). Belajar dan Pembelajaran. Fitrah Jurnal Kajian Ilmu-Ilmu Keislaman, Vol. 03(No. 02), 15.

Dwi, F. K. \& Rahayu. (2017). Pengaruh Model Pembelajaran Discovery Learning Terhadap Hasil Belajar Siwa Kelas 4 SD. Scholaria, Vol. 6(No. 2).

Fajri, Z. (2019). Model Pembelajaran Discovery Learning dalam Meningkatkan Prestasi Belajar Siswa SD. JURNAL IKA, Vol.7(No. 2), 65-66.

Hosman, M. (2014). Strategi Pembelajaran di Kelas. Bandung: Raja Grafindo.

Jones, J. L., \& Hilaire, R. (2012). Concept Learning in the Undergraduate Classroom: A Case Study in Religious Studies. International Journal of Instruction, Vol. 07(No. 02), 66.

Kosmiyah. (2012). Belajar dan Pembelajaran. Yogyakarta: Teras.

Majid, A. (2014). Belajar dan pembelajaran:Pendidikan Agama Islam. Bandung: Remaja Rosdakarya.

Mutmainna, F. (2015). Komparasi Hasil Belajar Fisika Melalui Metode Discovery Learning dan Assignment and Recitation. Jurnal Pendidikan Fisika, Vol. 3(No. 1, ISSN 2355-5785), 2015.

Ningsih, A. B. (2012). Belajar dan Pembelajaran. Jakarta: Rineka Cipta.

Nurkholis. (2013). Pendidikan Dalam Upaya Memajukan Teknologi. Jurnal Kependidikan, Vol. $1(1), 24-25$.

Perdana, R. (2019). Perbandingan Model Pembelajaran Learning Cycle 5E Dengan Model Tradisional Dalam Menigkatkan Kognitif Siswa. SCAFFOLDING: Jurnal Pendidikan Islam $\begin{array}{lllllll}\text { dan } & \text { Multikulturalisme } & \text { Vol } & 1 & \text { No } & 01 & \text { (2019). }\end{array}$ https://doi.org/10.37680/scaffolding.v1i01.40

Priyayi, D. F., Sajidan, \& Prayitno, B. A. (2015). Pengembangan Model Pembelajaran Accelerated Learning Included By Discovery (Alid) pada Materi Jaringan Tumbuhan Kelas XI SMA Negeri 7 Surakarta. JURNAL INKUIRI ISSN: 2252-7893, Vol. 3(No. II), 4-5.

Purwaningrum, J. P. (2016). Mengembangkan Kemampuan Berfikir Kreatif Mtematis Melalui Disovery Learning Berbasis Sceintific Approach. Jurnal Refleksi Edukatika, Vol. 06(No 02).

Rinjani, A. (2018). Analisis data kualitatif. Jurnal Alhadharah, Vol. 17(NO. 33).

Sibuea, S. K., Syaukani \& Nasution (2019). Penerapan Model Discovery Learning dalam Pembelajaran Sejarah Kebudayaan Islam di MTs Darul Hikmah TPI Medan. Shomali Kurnia EDU-RILIGIA, Vol. 3(No. 3), 337-339.

Sutarto. (2016). Teori Kognitif dan Implikasinya dalam Pembelajaran. Yogyakarta: Ar- Ruzz Media,.

Uno, H. B. (2006). Orientasi Baru Dalam Psikologi Pembelajaran,. Jakarta: Bumi Aksara. 
Widyaningrum, R. (2015). Tahapan J Bruner dalam Pembelajaran Matematika pada Penjumlahan dan Pengurangan Bilangan Bulat di Sekolah Dasar (SD/MI). Cendekia, Vol. 9(No.01), 75.

Widyawati, A. (2014). Metode Mengajar sebagai strategi dalam mencapai tujuan belajar mengajar. , Jurnal Pendidikan Akuntansi Indonesia, Vol.3(No. 1), 68.

Windi, W. M. B., Akbar, P., \& Sugandi, A. I. (2019). Penerapan Strategi Pembelajaran Aktif Question Student Have untuk Meningkatkan Kemampuan Berpikir Kritis Matematik Siswa SMK. Jurnal Cendekia: Jurnal Pendidikan Matematika, Vol.3(No. 1), 24.

\section{Wawancara:}

Miftakul Jannah, guru PAI di kelas VII SMPN 3 Depok Sleman, pada 21 April 2020

Murdiwiyono (2020), Kepala SMPN 3 Depok Sleman, pada 22 April 2020

Rosiyah dan Sholahudin, siswa kelas VII SMPN 3 Depok Sleman, pada 21 April 2020 